lov kan vi slå op. Det er i højere grad historiebevidsthed, som vi har brug for indsigt i, og det er her idéhistorikeren skal på banen.

Jørgensen er tydeligvis klar over, at hvis man vil kritisere uden at forfalde til brok, må man også komme med et alternativ, og her tilbyder hun selv skønheden. Det vanskelige ved Jørgensens projekt er bare, at hun samtidig med at overbevise også skal omskole til en helt anden måde at tænke æstetik på, end den som i de sidste mindst 100 år har gjort sig gældende.

Aglaias Dans henvender sig både til faste tilhængere af Jørgensen, som vil læse sig dybere ind $\mathrm{i}$ æstetikken som kritisk tænkning, og til læseren, som ønsker korte introduktioner til den filosofiske æstetik. Men den tjener også i høj grad, og måske vigtigst, som en opfordring til efterfølgelse. Uanset om man anser æstetikken som en gang lommefilosofisk føleri, eller om man anerkender dens fordring på sandhed, formår Jørgensen, om ikke andet, at reflektere over, hvad idéhistorien er og kan være, og hvad den kan bidrage med over for den bredere befolkning. Visdom er ikke forbeholdt de få ophøjede i elfenbenstårnet, men bør være tilgængelig for alle. Jørgensen har en idé om, hvordan denne opgave skal angribes. Har du?
MARTIN BLOK JOHANSEN

\section{Distanceret involverethed eller involveret distance?}

Mogens Pabuus: Distance og involverethed - et tema i eksistenstankning og elesistensdigtning, Aalborg Universitetsforlag, 2008, 160 sider, 199,- kr.

Året efter at han havde udgivet sin disputats om Søren Kierkegaard, Kierkegaard. Konstruktion des Ästhetischen, skriver Theodor Adorno til sin ven, den østrigske komponist Ernst Krenek, at professor Gomperz fra universitetet i Wien mente, at i Adornos Kierkegaard-bog "var det egentlig kun citaterne, der var interessante". Noget lignende kunne man sige om Mogens $\mathrm{Pa}$ huus' bog om eksistenstænkning og eksistensdigtning, Distance og involverethed. Hvis man var fræk og kæk nok. Det er jeg ikke, så jeg nøjes med at sige, at citaterne i Pahuus' bog er meget interessante. Hvis de bliver opfattet som det mest interessante, er det ikke Pahuus' skyld. Eller, så er det netop Pahuus'skyld. Pahuus er nemlig eminent, når det handler om at opspore og fremdrage de mest elegante, fornøjelige og mesterlige citater fra de værker, han bruger. Fx når Milan Kundera i Langsombeden kalder forbindelsen mellem langsomhed og nydelse 
for "en sødmefuld ladhed", fx Kierkegaards appel om at "spatiere Momentet" og fx Peter Seebergs barske bonmot: "Man kan ikke forarges over virkeligheden, selvom den er hæslig".

Distance og involverethed er tredje selvstændige bind i Mogens Pahuus' række af bøger om litteratur og filosofi. Første bind fra 2005 hedder H.C. Andersens livsfilosofi. Heri læser Pahuus H.C. Andersens værker som erkendelsesformuleringer. Det drejer sig primært om de symbolske eventyr, men også Andersens fem romaner og erindringsbøgerne inddrages. Pahuus' postulat er, at Andersens eventyr ikke i tilstrækkeligt omfang er blevet forstået og fortolket som den anskueliggørelse af eksistentielle grundforhold og grundforløb, som de er. Herefter følger tolkninger af H.C. Andersens syn på menneskets natur og livsmuligheder, analyser af længselselementet og dannelseselementet, af den erotisk bestemte kærlighed og af seksualiteten, præsentation af H.C. Andersens syn på værdierne i tilværelsen og en afsluttende sammenligning af H.C. Andersen livsfilosofi med tre af de samtidige digteres og tænkeres livsfilosofi: Adam Oehlenschläger, Kierkegaard og Frederik PaludanMüller. Andet bind fra 2007 hedder Tombedsfolelse og ondskab. Værket er umiddelbart todelt: et afsnit om tomhedsfølelse, hvor der - med inddragelse af fx Jørgen Nielsen, Pär Lagerkvist, Herman Bang og H.C. Branner - reflekteres over, hvad der er bestemmende for, om tilværelsen bliver præget af tomhed eller fylde, opfyldelse og meningsfuldhed, og et afsnit om ondskab, hvor der - med inddragelse af Fjodor Dostojevskij og Martin A. Hansen - reflekteres over, hvorfra og hvorfor viljen til ondskab kommer. Men todelingen er kun foreløbig, for Pahuus' ærinde er at vise, at der er en betydningsfuld sammenhæng mellem tomhedsfølelse og ondskab.

Denne måde at opbygge et værk på er karakteristisk for Pahuus, og den kommer også til udtryk i dette tredje bind. Værket er inddelt i fire kapitler, men er egentlig todelt. I den første del sammentænkes eksistensfilosofi og livsfilosofi, hvor eksistensfilosofien repræsenteres af Kierkegaard og Martin Heidegger, mens livsfilosofien repræsenteres af K.E. Løgstrup. Det er Pahuus' gennemgående pointe, at eksistensfilosofien i særlig grad knytter an til den distance, der er forbundet med menneskets forholden sig til sig selv og til verden, mens livsfilosofien i særlig grad knytter an til den involverethed, der er forbundet med den åbne og selvforglemmende optagethed af verden og sig selv. I den anden del præsenteres og diskute- 
res tre forfattere, der i særlig grad har fokuseret på forholdet mellem netop distance og involverethed: Albert Camus, Peter Seeberg og Milan Kundera. Pahuus fremviser forsøgsvis et slægtskab mellem de livsforståelser, der er indeholdt i de tre forfatterskaber. I den første del udfolder Pahuus således dels en eksistensfilosofisk tænkemåde og dels en livsfilosofisk. I den eksistensfilosofiske tænkemåde er man optaget af to sider hos mennesket. For det første, at man bestandigt må forholde sig til sig selv og sin situation. For det andet, at man ikke vil påtage sig sit liv som en opgave; man vil ikke være sig selv og lever i uegentlighed. I den livsfilosofiske tænkemåde er man optaget af to radikalt andre sider hos mennesket. For det forste, at mennesket er i verden med vitalitet og en evne til åbenhed for og selvforglemmende optagethed af verden. For det andet, at netop det at være sig selv giver sig selv, når man er båret af den selvforglemmende optagethed.

Eksistensfilosofien, der er knyttet til den distance, der er forbundet med menneskets forholden sig til sig selv og til verden, og livsfilosofien, der er forbundet med den involverethed, der er knyttet til den åbne og selvforglemmende optagethed af verden og sig selv, anvendes $\mathrm{i}$ de tre efterfølgende kapitler, der bedst kan betragtes som bogens anden del, på Camus, Seeberg og Kundera. Det er Pahuus' pointe, at for disse tre forfattere er den form for involverethed, hvor man lever i blind overtagelse af de overleverede værdier, en illusion. For Camus i Sisyfosmyten har det absolutte, den absolutte mening, som kristendommen foregav at kunne levere, vist sig at være en illusion, for Seeberg er det Indre Mission ("dette uovergåelige alvorshysteri”), og for Kundera er det først kommunismens erstatningsreligion og derefter de moderne vestlige landes livsholdning. De tre forfattere vedkender sig, at verden og tilværelsen ikke har en given mening. Det er op til det enkelte menneske at give tilværelsen mening. At gøre tilværelsen meningsfuld er det samme som at komme til at leve på en involveret måde. Men det bliver en involverethed, der har indoptaget distancen og letheden i sig. Den nye mening og involverethed kræver for de tre forfattere, at man bevidst og illusionsløst fastholder bevidstheden om livets mangel på mening: For Camus betyder det, at man skal fastholde oprøret mod det givne, for Seeberg betyder det, at man skal undgå selvmedlidenhed og selvbedrag, og for Kundera betyder det, at man ikke må lade sig kue af alvorsånden, imagologien eller den kunstige optimisme. Det er afslutningsvis Pahuus' konklusion, at 
involveretheden og distancen bør sammentænkes. "Intensiteten i vort liv er knyttet til den involverethed, hvor vi er selvforglemmende optaget af tingene og de andre", skriver han, "men vi har også brug for at kunne få distance til situationen for virkelig at kunne forholde os til den - i frihed og selvstændighed".

Pahuus færdes sikkert og hjemmevant $i$ sin fremstilling af eksistensfilosofi og livsfilosofi. Selve fremstillingen er klar (fraregnet små redaktionelle svipsere som fx "Løstrup", "Kierkegaard kommer til at opererer med", "synet af båden give ham lyst til" og flere andre) og på et højt fagligt niveau - også i behandlingen af det litterære stof. $\mathrm{Og}$ eftersom grundtemaet $i$ det litterære stof på mange måder udgøres af de eksistensfilosofiske og livsfilosofiske nøglebegreber, distance og involverethed, kan bogen tillige fungere som en introduktion - ikke blot til væsentlige grundtanker inden for eksistens- og livsfilosofi, men tillige til centrale tematikker i Camus', Seebergs og Kunderas forfatterskaber.

Man kunne indvende, at begrundelserne og argumentationen i bogen ikke altid er lige overbevisende. Fx forfalder Pahuus jævnligt til argumentfraværende ordsprog: "Det er som bekendt lysten, der driver værker" (s. 25). Det ville også være lige til at indvende, at eksistensfilosofien undertiden omsættes til Femina-visdom: "Hvis al vor livsudfoldelse havde karakter af det at klare, da ville vort liv være fattigere, end det faktisk er" (s. 23), i livsudfoldelsen "åbner vi os helt og fuldt for tingene omkring os og de andre. Da bliver vi opladte. Vi er ikke målrettede, er ikke ude på noget, men åbner os for alt det givne og glæder os over det" (s. 23). "Man opdager kun, hvad man selv rummer, og hvilke evner man har, når man tager sin vilje $\mathrm{i}$ brug $\mathrm{og}$ investerer flid og koncentration i det, man har lyst til at gøre" (s. 25). Man kunne også indvende, at Pahuus' klinkevals med de store tænkere til tider virker upassende (fx "Heidegger har ret $[. .$.$] men han tager fejl,$ når han tror $[. .$.$] " og "men Camus$ kan ikke se denne begrænsethed") og direkte parodisk, når årvågne Pahuus ser en masse, som "vore tre forfattere er tilbøjelige til at overse" (s. 147) og en masse andre ting, som "disse tre forfattere også er tilbøjelige til at overse" (s. 149). Indvendingerne er imidlertid på mange måder uvæsentlige. Pahuus har et ærinde med sin bog, som han forfølger. Præcist og loyalt i forhold til kernebegreberne, distance og involverethed. Og netop fordi det er så loyalt over for begreberne, kunne det have været interessant og måske oplysende, hvis Pahuus havde indledt sin bog med 
en sproglig analyse og afdækning af de to kernebegreber, både etymologisk og semantisk. Distance kommer til det danske sprog gennem fransk fra latin distantia afledt af distare, der betyder 'stå i afstand fra'. Det er vel netop denne ståen i afstand fra, der også kendetegner eksistensfilosofien. Eksistens kommer etymologisk af de latinske eksistentia, der betyder 'stå ud af'. Denne ståen ud af, som eksistensfilosofien tematiserer, er netop den ståen $\mathrm{i}$ afstand fra, som distancen udtrykker. Noget lignende med involveretheden. Involvere er fra latin og betyder 'rulle frem, indhylle'. Det er livsfilosofiens åbne og selvforglemmende optagethed af verden og sig selv: når verden ruller frem, og man lader sig indhylle af den.

Der er masser af potentiale i Distance og involverethed. Som læser bliver man udfordret, ansporet og anfægtet. På et tidspunkt i bogen skriver Pahuus, at "når livet ikke længere er forankret i noget absolut, indebærer det også, at ens længsel efter det absolutte aldrig kan finde opfyldelse" (s. 88) og senere, at "man kan ikke leve alene på overleverede erfaringer af det sjælelige og det åndelige. Disse fænomener er heller ikke bundet til bestemte livsformer og dermed til bestemte udtryksformer - religiøse, filosofiske, kunstneriske. Man må selv have del i disse erfaringer" (s. 149). Men kan man få for meget del i disse erfaringer? Er det sandt, at "længslen aldrig kan finde opfyldelse", og er det ikke netop den massive ulempe, at de sjælelige og åndelige erfaringer ikke alene er bundet til det religiøse, filosofiske eller kunstneriske? Hvis vi forestiller os, at den menneskelige eksistens er defineret af en smerte, fx smerten ved ikke altid at være i centrum eller smerten ved, at vores længsel altid overgår vores midler til at tilfredsstille længslen. Og hvis vi tilmed forestiller os, at religion, filosofi og kunst er vores foretrukne måder til at forsone os med den smerte, hvad sker der så med religion, filosofi og kunst? Hvis $\mathrm{fx}$ internettet gør os i stand til at blive centrum, når vi ønsker det, og hvis det gør os i stand til at få tilfredsstillet vores dybeste længsler, når vi ønsker det. Hvor efterlader det distancen og involveretheden? 